\title{
FOOTWEAR PROTECTION AGAINST FUNGI USING THYME ESSENTIAL OIL
}

\author{
Corina CHIRILĂ, Viorica DESELNICU, Mariana Daniela BERECHET
}

INCDTP - Division Leather and Footwear Research Institute, 93 lon Minulescu st., sector 3, 031215 Bucharest

ABSTRACT. Many natural antimicrobial agents have been identified over the last decades, such as essential oils, which have a proven effect against bacteria and fungi found on feet. This paper investigates antifungal activity of thyme essential oil against Trichophyton interdigitale on sheepskins for footwear lining. Thyme essential oil showed the best antifungal activity on sheepskins for footwear lining. Thyme oil offers a much safer alternative to toxic biocides. The results of this study may have potential for use in the development of applications in the sanitation of footwear components.

KEY WORDS: sheep skins lining leather, thyme essential oil, antifungal activity, Trichophyton interdigitale

\section{PROTEJAREA ÎNCĂLTĂMINTEI ÎMPOTRIVA FUNGILOR UTILIZÂND ULEIUL ESENTIAL DE CIMBRU}

REZUMAT. Numeroşi agenţi antimicrobieni naturali au fost identificaţi în ultimele decenii, printre aceștia numărându-se uleiurile esenţiale, care au un efect dovedit împotriva bacteriilor şi ciupercilor întâlnite la nivelul picioarelor. Această lucrare investighează activitatea antifungică a uleiului esenţial de cimbru împotriva ciupercii Trichophyton interdigitale asupra pieilor de oaie pentru căptuşirea încălţămintei. Uleiul esenţial de cimbru a prezentat cea mai bună activitate antifungică asupra pielii de oaie pentru căptuşirea încălţămintei. Uleiul de cimbru oferă o alternativă mult mai sigură la biocidele toxice. Rezultatele acestui studiu pot fi utilizate în dezvoltarea aplicaţiilor în igiena componentelor încălţămintei.

CUVINTE CHEIE: piei de oaie pentru căptușeală, ulei esenţial de cimbru, activitate antifungică, Trichophyton interdigitale

\section{LA PROTECTION DES CHAUSSURES CONTRE LES CHAMPIGNONS EN UTILISANT L'HUILE ESSENTIELLE DE THYM}

RÉSUMÉ. De nombreux agents antimicrobiens naturels ont été identifiés au cours des dernières décennies, telles que les huiles essentielles, qui ont un effet éprouvé contre les bactéries et les champignons trouvés sur les pieds. Cet article étudie l'activité antifongique de l'huile essentielle de thym contre Trichophyton interdigitale sur les peaux de mouton pour la doublure de la chaussure. l'huile essentielle de thym a présenté la meilleure activité antifongique sur les peaux de mouton pour la doublure de la chaussure. L'huile de thym offre une alternative beaucoup plus sûre aux biocides toxiques. Les résultats de cette étude peuvent être utilisés dans le développement d'applications pour l'assainissement des composants de la chaussure.

MOTS CLÉS: peaux de moutons pour la doublure, huile essentielle de thym, activité antifongique, Trichophyton interdigitale

\section{INTRODUCTION}

Odour is a key factor in limiting footwear lifetime as the causative compounds do not disappear immediately. It arises when sweat from feet is trapped inside the footwear materials and their components are degraded by feet microbiota [1]. A way to avoid or reduce bad shoe odours apart from foot care and hygiene measures is through the use of antimicrobial and/or deodorising agents. A wide range of antimicrobial compounds are commercially available. In the footwear industry, suitable antimicrobial technologies are mainly focused on metals and metal compounds (e.g. silver, copper, zinc, metal oxides, etc.). A few other compounds such as quaternary ammonium salts, borates, 2,4,4-trichloro-2-hydroxydiphenil ether (Triclosan) or 3-iodo-2-propynyl-butylcarbamate (IPBC), etc., are also used. However some of them may in some degree be extremely irritant, harmful and toxic for the environment and human health [2].

Many natural antimicrobial agents have been identified over the last decades, such as essential oils, which have a proven effect against bacteria and fungi found on feet.

The antifungal properties of essential oils have been thoroughly researched. Studies prove conclusively that certain essential oils work as powerful antifungals [3-5]. Some essential oils have the ability to kill parasites and fungal infections, which is why they are so popular for use in fighting toenail fungus, ringworm and athlete's * Correspondence to: Corina CHIRILĂ, INCDTP - Division Leather and Footwear Research Institute, 93 Ion Minulescu st., sector 3, 031215
Bucharest, e-mail: corina.chirila@icpi.ro 
foot [6-10]. Athlete's foot, also known as tinea pedis, is a fungal infection that affects the foot. It causes redness, peeling of skin, burning, itching and sometimes blisters and sores. Athlete's foot is a very common fungal infection. The fungus thrives best in a moist, warm environment such as wet socks, shoes, swimming pools, locker rooms, and wet floors of showers. Its occurrence is most common in summer and in warm, humid climates. It is frequently reported in people who wear tight shoes such as sneakers [11].

Keeping in mind the adverse reactions of antifungal medicines, natural remedies are a safe choice to treat fungal infections. They have no undesirable side effects or nasty drug interactions. Essential oils are a natural remedy for getting rid of fungal infections. Many essential oils have the capability to combat fungal infection. These oils are made up of complex chemical constituents, and researchers have found that many essential oils have antifungal properties. If used properly, essential oils with antifungal traits are a natural way to cure fungal diseases such as athlete's foot [11].

Kalemba and Kunicka [12] reported that essential oils derived from spices and herbs have some of the strongest antifungal properties. These essential oils include cinnamon, mint, thyme, sage, clove and origanum. Furthermore, Price and Price [13] list pine, tea tree, peppermint, basil and rosemary essential oils as having antifungal properties. Tea tree oil, especially, is proven to be effective against candida. This fact has been established in several studies, such as that of Shemesh and Mayo [14].

Thyme (Thymus vulgaris) is an herbal plant commonly used as a condiment or spice. Thyme oil and extracts are often used as an essential ingredient in many of the domestic herbal remedies. This essential oil contains thymol (natural monoterpene phenol derivative of cymene) that is beneficial for controlling infection caused by fungal and bacterial influence. It works exceedingly well for getting rid of toenail fungus [15].

According to one of the studies which examined the antifungal effects of a generic test rub, it is found that using thymol effectively suppressed the fungus that is responsible for toenail infection. Another study reported the effectiveness of thymol in eliminating candida fungus [16].

Extended studies were already reported for using essential oils as biocides in leather manufacture [17-21] and in footwear protection against microorganism growth which are mainly responsible for shoe bad odor [22-25].

The aim of this work is to test antifungal activity of essential oil extracted from thyme (Thymus vulgaris) against Trichophyton interdigitale on sheepskin leather used as lining in footwear production, in order to avoid or reduce bad shoe odour through the use of antimicrobial and/or deodorising agents.

\section{MATERIALS AND METHODS}

\section{Materials}

Essential oil isolated from thyme (Thymus vulgaris) was obtained by hydro distillation in a continuous Clevenger extractor [26];

Sheep skins for footwear linings unfinished and finished with synthetic film;

Biologic material: Trichophyton interdigitale.

\section{Methods}

Chemical composition of essential oils was determined by Gas chromatography-Mass Spectrometry (GC-MS) with Agilent 6890 N [26].

Antifungal activity against Trichophyton interdigitale: The tests were performed in accordance with ASTM D4576-86:2013 - Standard Test Method for Mold Growth Resistance of Wet Blue.

In each Petri dish Dextrose Agar Sabouraud culture medium was poured. Both samples treated with thyme essential oil and control samples were placed in each Petri dish in the center of the surface of the culture medium, and then the culture medium was seeded in 3 points around the sample, as an equilateral triangle. There have been two parallel samples. Petri dishes were placed in thermo-hygrostat at $30^{\circ} \mathrm{C}$ temperature and were analyzed after 3,7 , 14 and 21 days. 
Optical microscopy images were captured using a Leica stereomicroscope S8APO model with optic fiber cold light source, L2, with three levels of intensity, and magnification 40X.

\section{RESULTS AND DISCUSSION}

\section{Chemical Composition of Thyme Essential Oil}

Table 1 presents the main components of thyme essential oil determined by GC/GC-MS chromatography.

Table 1: Main chemical compounds identified in Thymus vulgaris essential oil

\begin{tabular}{|c|c|c|c|c|c|}
\hline No. & Retention time, $\min$ & Compound & Formula & $\%$ & $\begin{array}{c}\text { Kovats } \\
\text { Indices, } \mathrm{KI}\end{array}$ \\
\hline 1 & 23.060 & Carvacrol (Antioxine) & $\mathrm{C}_{10} \mathrm{H}_{14} \mathrm{O}$ & 57.355 & $2,291 \times 10^{3}$ \\
\hline 2 & 12.940 & Thymol & $\mathrm{C}_{10} \mathrm{H}_{16}$ & 32.430 & $1,095 \times 10^{3}$ \\
\hline 3 & 11.240 & o-Cymol & $\mathrm{C}_{10} \mathrm{H}_{14}$ & 3.993 & $1,057 \times 10^{3}$ \\
\hline
\end{tabular}

Analysis allowed the identification of 16 components of which, carvacrol $(57.355 \%)$ and thymol (32.430\%) and o-cymol (3.993\%) were detected as major constituents.

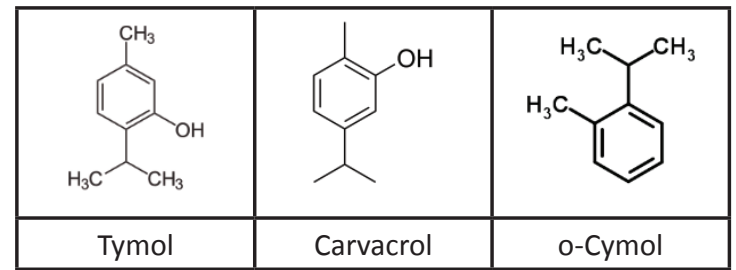

Thymol is a natural monoterpene phenol derivative of cymene, $\mathrm{C}_{10} \mathrm{H}_{14} \mathrm{O}$, isomeric with carvacrol; carvacrol, or cymophenol, $\mathrm{C}_{6} \mathrm{H}_{3} \mathrm{CH}_{3}(\mathrm{OH})$ $\left(\mathrm{C}_{3} \mathrm{H}_{7}\right)$, is a monoterpenoid phenol; o-cymol is o-isopropyltoluol.

\section{Antifungal Activity}

Table 2 presents antifungal activity against Trichophyton interdigitale after 3, 7, 14 and 21 days of incubation at $30^{\circ} \mathrm{C}$ of sheepskin leather treated with thyme essential oil.

Figure 1 . The main components of thyme essential oil

Table 2: Antifungal activity on sheepskin unfinished leather for lining treated with thyme essential oil against Trichophyton interdigitale

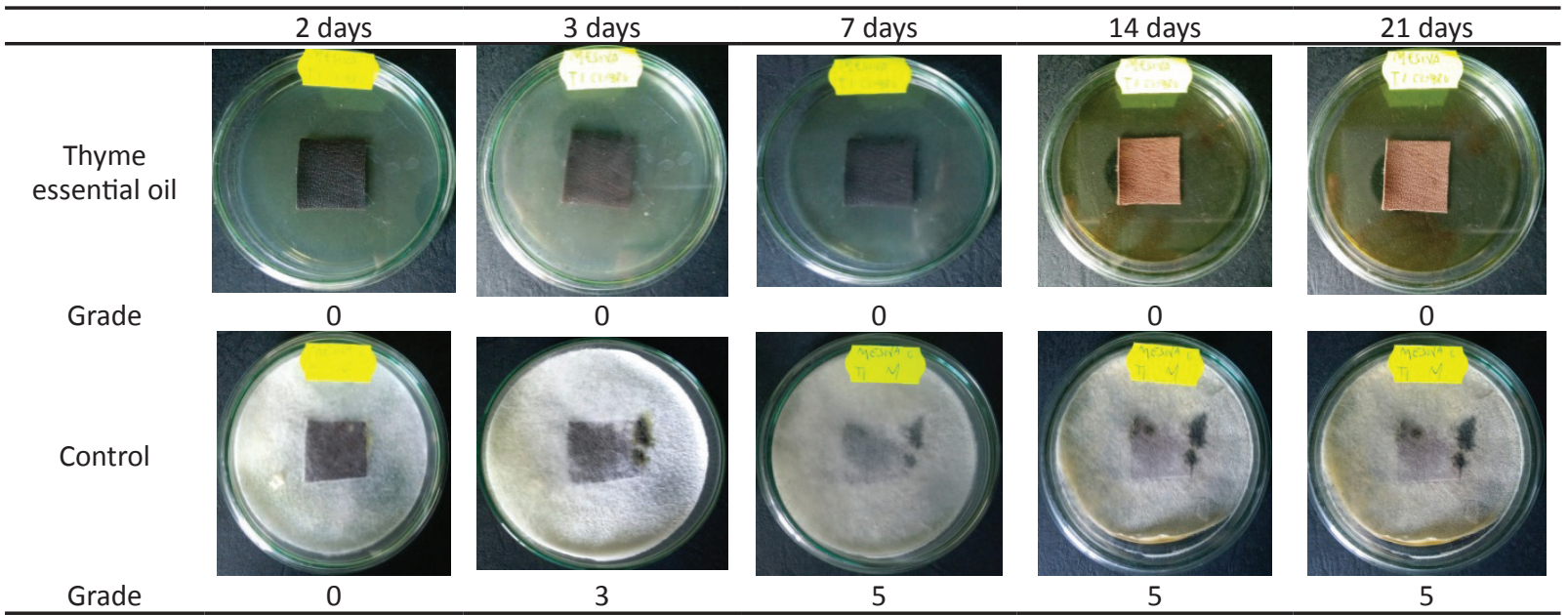


The thyme essential oil applied on lining leather completely inhibited the development of the Trichophyton interdigitale, with no increases until the end of the 21-day experiment. In the control samples, increases were observed after 2 days, and at the end of the experiment ( 21 days) the leather samples were completely covered by the pathogen.

Table 3 presents antifungal activity against Trichophyton interdigitale after 3, 7, 14 and 21 days of incubation at $30^{\circ} \mathrm{C}$ of sheepskin leather finished with synthetic film and treated with thyme essential oil.

Table 3: Antifungal activity on sheepskin leather for lining finished with synthetic film and treated with thyme essential oil against Trichophyton interdigitale

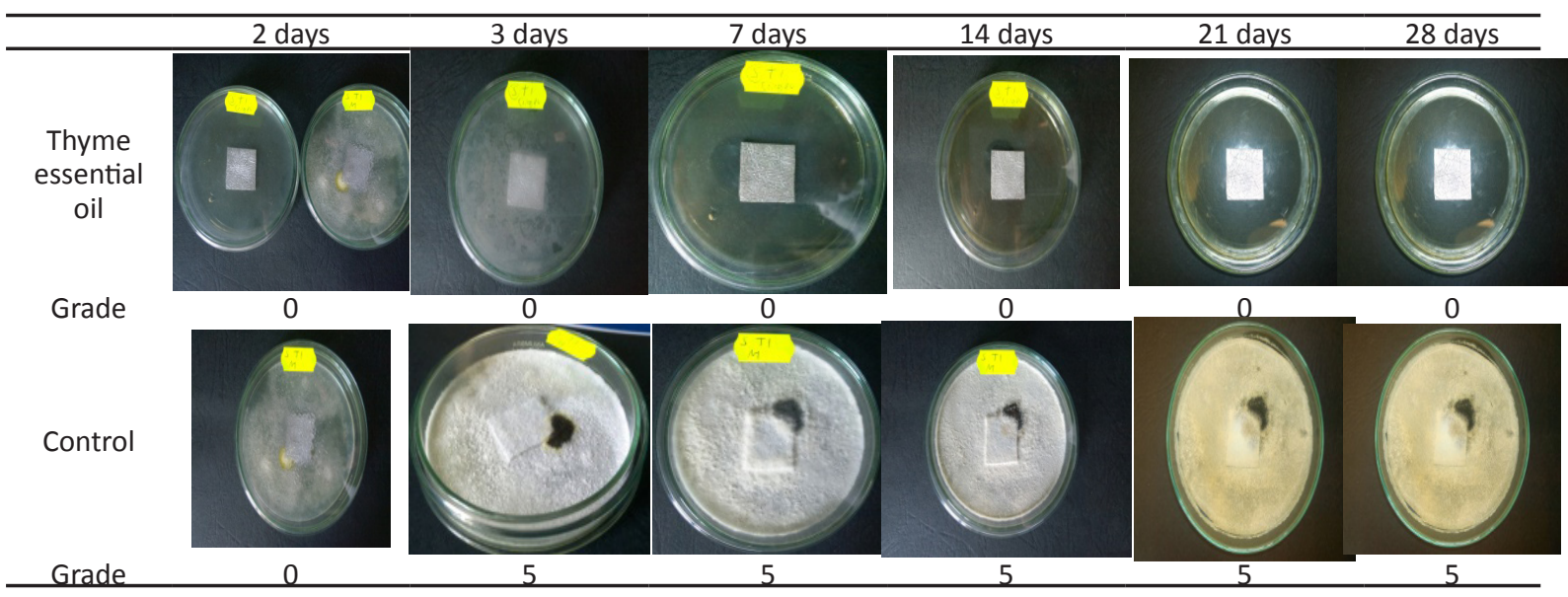

Thyme essential oil applied on sheepskin leather for lining finished with synthetic film has completely inhibited the development of the Trichophyton interdigitale species, with no increases until the end of the experiment 28 days. In the control samples, increases of pathogen were observed after 2 days; after 7 days the leather samples were completely covered by the pathogen, the synthetic film failing to protect the leather.

\section{CONCLUSION}

The results obtained in this study show that Thymus vulgaris oil exhibited high antifungal activity against Trichophyton interdigitale. Thyme oil proved to be the best inhibitor of fungi conferred by high thymol and/or carvacrol content. Thyme oil offers a much safer alternative to toxic biocides.

The results of this study may have potential for use in the development of applications in the sanitation of footwear components.

\section{Acknowledgements}

This study was financed by the Ministry of Research and Innovation in the framework of Nucleu Program INOVA-TEX-PEL, 2016-2017, contract 26/2016, project code PN 16340205.

\section{REFERENCES}

1. Ara, K., Hama, M., Akiba, S., Koike, K., Okisaka, K., Hagura, T., Kamiya, T., Tomita, F., Foot Odour Due to Microbial Metabolism and its Control, Can J Microbiol, 2006, 52, 4, 357364.

2. Sánchez-Navarro, M.M., Pérez-Limiñana, M.A., Cuesta-Garrote, N., Maestre-López, M.I., Bertazzo, M., Martínez-Sánchez, M.A., Orgilés-Barceló, C., Arán-Aís, F., Latest Developments in Antimicrobial Functional Materials for Footwear, in A. Méndez-Vilas (ed.), Microbial Pathogens and Strategies for Combating them: Science, Technology and Education, 2013, Formatex Research Center.

3. Niculescu, O., Leca, M., Moldovan, Z., Deselnicu, D.C., Research on Obtaining Products for Fragrance and Biological 
Protection on Natural Leathers and Furs, Rev Chim Bucharest, 2015, 66, 12, 1956-1959.

4. Radwan, I.A., Abed, A.H., Abeer, M.R., Ibrahim, R.A., Abdallah, A.S., Effect of Thyme, Clove and Cinnamon Essential Oils on Candida albicans and Moulds Isolated from Different Sources, American Journal of Animal and Veterinary Sciences, 2014, 9, 4, 303-314.

5. Steviæ, T., Beriæ, T., Šavikin, K., Sokoviæ, M., Goðevac, D., Dimkiæ, I., Stankoviæ, S., Antifungal Activity of Selected Essential Oils against Fungi Isolated from Medicinal Plant, Ind Crops Prod, 2014, 55, 116-122.

6. Niculescu, O., Leca, M., Moldovan, Z., Deselnicu, D.C., Obtaining and Characterizing of a Product with Antifungal Properties Based on Essential Oils and Natural Waxes for Finishing Natural Leathers, Rev Chim Bucharest, 2015, 66, 11, 1733-1736.

7. Bayramoðlu, E.E., Gülümser, G., Karaboz, I., The Investigation of Antibacterial Activities of Some Essential Oils in Wet Blue Leather, International Journal of Natural and Engineering Sciences, 2008, 2, 1, 33-36.

8. Chirila, C., Crudu, M., Deselnicu, V., Comparative Study Regarding Resistance of Wet-White and Wet-Blue Leather to the Growth of Fungi, Leather and Footwear Journal, 2014, 14, 2, 107-120.

9. Chirila, C., Crudu, M., Deselnicu, V., Study Regarding the Resistance to the Growth of Fungi of Wet-White Leather Tanned with Titanium - Aluminum, Proceedings of The 5th ICAMS 2014, 23-25 October 2014, Bucharest, 31-36.

10. Chirila, C., Deselnicu, V., Crudu, M., Study Regarding the Resistance of Wet-White Leather Organic Tanned to the Growth of Fungi, Proceedings of The 5th ICAMS 2014, 23-25 October 2014, Bucharest, 37.

11. https://medlicker.com/1088-essential-oilsfor-fungal-infections

12. Kalemba, D., Kunicka, A., Antibacterial and Antifungal Properties of Essential Oils, Curr Med Chem, 2003, 10, 10, 813-29.

13. Price, L., Price, S., Aromatherapy for Health Professionals, 2007, Elsevier Health Sciences.
14. Shemesh, A., Mayo, W.L., Australian Tea Tree Oil: A Natural Antiseptic and Fungicidal Agent, Australian Journal of Pharmacy, 1991, 72, 802-803.

15. Ramsewak, R.S., Nair, M.G., Stommel, M., Selanders, L., In vitro Antagonistic Activity of Monoterpenes and Their Mixtures Against 'Toe Nail Fungus' Pathogens, Phytother Res, 2003, 17, 376-379, https://doi.org/10.1002/ ptr.1164.

16. Braga, P.C., Alfieri, M., Culici, M., Dal Sasso, M., Inhibitory Activity of Thymol against the Formation and Viability of Candida albicans hyphae, Mycoses, 2007, 50, 502-506, https:// doi.org/10.1111/j.1439-0507.2007.01412.x.

17. Berechet, M.D., Chirila, C., Deselnicu, V., Antifungal Activity of Thyme Essential Oil on Woolen Sheepskins, Proceedings of The 6th ICAMS 2016, 203-208, 20-23 October 2016, Bucharest.

18. Chirila, C., Berechet, M.D., Deselnicu, V., Thyme Essential Oil as Natural Leather Preservative against Fungi, Proceedings of The 6th ICAMS 2016, 227-232, 20-23 October 2016, Bucharest.

19. Chirila, C., Crudu, M., Deselnicu, V., Comparative Study regarding Resistance of Wet-White and Wet-Blue Leather to the Growth of Fungi, Leather and Footwear Journal, 2014, 14, 2, 107-120, https://doi. org/10.24264/Ifj.14.2.4.

20. Chirila, C., Crudu, M., Deselnicu, V., Study regarding the Resistance to the Growth of Fungi of Wet-White Leather Tanned with Titanium-Aluminum, Proceedings of The 5th ICAMS 2014, 23-25 October 2014, Bucharest, RO, 31-36, ISSN: 2068-0783, CERTEX press.

21. Chirila, C., Deselnicu, V., Crudu, M., Study regarding the Resistance of Wet-White Leather Organic Tanned to the Growth of Fungi, Proceedings of The 5th ICAMS 2014, 23-25 October 2014, Bucharest, 37-42, RO, ISSN: 2068-0783, CERTEX press.

22. Deselnicu, D.C., Vasilescu, A.M., Purcarea, A.A., Militaru, G., Sustainable Consumption and Production in the Footwear Sector, Leather and Footwear Journal, 2014, 14, 3, 159-180. 
23. Deselnicu, V., Deselnicu, D.C., Vasilescu, A.M., Militaru, G., EU Policy for Sustainable Consumption and Production - EU Ecolebal for Footwear, Proceedings of the 5th International Conference on Advanced Materials and Systems ICAMS 2014, 23-25 October 2014, Bucharest, 641-646.

24. Deselnicu, V., Maier, S.S., Albu, L., Buruntea, N., Antimicrobial and Antifungal Leathers for Increasing the Health and the Comfort of the Individuals, CORTEP, 2007, 18-21 Oct., lasi, RO.

25. Deselnicu, V., Maier, S.S., Deselnicu, O.C., Florescu, M., Impact of Technological Changes on Increased Health and Comfort Efficiency, Proceedings of The 4th International Conference in Management of Technological
Change, Book 1, Chania, Greece, 19-20 August 2005, 87-92.

26. Berechet, M.D., Essential Oils - Their Use in Practice and Research, Doctoral Thesis, 2015, Faculty of Applied Chemistry and Materials Science, "Politehnica" University of Bucharest.

(C) 2017 by the author(s). Published by INCDTP-ICPI, Bucharest, RO. This is an open access article distributed under the terms and conditions of the Creative Commons Attribution license (http://creativecommons.org/licenses/ by/4.0/). 